http://doi.org/10.32437/NMHDUP2021.2

Вплив дистанцйної роботи на психічне здоров'я педагогів

Валентина Горленко,

Український науково-методичний центр практичної психології і соціальної роботи,

Київ, Україна

\title{
The impact of remote work on the mental health of teachers
}

Valentyna Horlenko

Ukrainian Scientific and Methodological Center of Applied Psychology and Social Work, Kyiv, Ukraine

\begin{abstract}
The paper highlights the results of a study of complications in the professional activities of teachers and their emotional state. Showing the analysis of the problem of complications in the execution of teachers' professional duties in the conditions of remote work and as a consequence - degradation of the emotional state, which is manifested in negative psychological symptoms. As a result of theoretical analysis, it was found that in different countries, studies of the emotional states of teachers during the COVID-19 pandemic are being conducted. To find out the complications in the professional activities and emotional state of teachers associated with the transition to distance learning in connection with quarantine, an online survey of teachers was conducted using the questionnaire "Identification of socio-psychological problems caused by the pandemic COVID-19 in the activities of educational institutions" developed by Panko V.H. Respondents were asked to assess the presence of the problem by scale where " 0 " - no presence; 1 - minimum presence; 10 - maximum presence. It was found that more than half of respondents $(\mathrm{N}=3209)$ have difficulties in carrying out professional activities in the conditions of remote work (inability to perform the full range of planned tasks and professional responsibilities; insufficient competence in ICT; difficulties with organizing time; disorders in communication between teachers and parents to control the quality of students' knowledge; difficulties with involving children in distance learning; complications with student discipline). As a result, respondents experience emotional exhaustion, decreased emotional balance and excessive fatigue. The results of the study confirmed the need for professional development and psychological assistance to teachers. The ways of psychological support of the educational process are outlined.
\end{abstract}

Keywords. remote work, emotional state, teacher, pandemic COVID-19. 
Пандемія COVID-19 стала викликом для усіх сфер життєдіяльності суспільства. За даними ЮНЕСКО (UNESCO, 2020), сфера освіти зазнала суттєвих змін: перерване навчання; стрес для вчительства; непідготовленість батьків до дистанційної домашньої освіти; проблеми, пов'язані зі створенням, підтримкою i вдосконаленням дистанційного навчання; погіршення догляду за дітьми; зростання випадків виключення із закладу освіти; збільшення рівня насильства та експлуатації; соціальна ізоляція; труднощі з вимірюванням та перевіркою засвоєння знань. Сьогоднішню ситуацію характеризує організація освітнього процесу у дистанційній формі із залученням інформаційно-комунікаційних технологій на тривалий термін. До цього часу педагоги України стикалися тільки з короткотривалим зупиненням освітнього процесу (карантинні заходи під час епідемій ГРИПу) і мали змогу надолужити освітні програми в післякарантинний період. Така ситуація суттєво впливає на емоційний стан педагогів, їх відношення до своєї професійної діяльності.

Ціла низка досліджень зарубіжних вчених спрямована на вивчення несприятливих психологічних симптомів, які виявляють педагоги в умовах пандемії. Педагогічні працівники відчувають певний тиск через використання методів онлайннавчання, поєднання потреб своєї сім'ї та багатогодинної роботи з дому (Aperribai et al.,2020; Brackett and Cipriano, 2020; Hidalgo-Andrade et al., 2021). Це призводить до того, що високий відсоток вчителів перебуває у стані стресу, занепокоєння та зниження настрою (Hidalgo-Andrade et al.,2021; Santamaría et al., 2021). Педагоги характеризують свій емоційний стан такими словами, як тривожний, зляканий, стурбований, пригнічений та сумний (Brackett and Cipriano, 2020) .

3 метою визначення впливу пандеміі і карантинних заходів на здійснення освітнього процесу в цілому та його учасників зокрема Українським науковометодичним центром практичної психології і соціальної роботи протягом 19 - 26 листопада 2020 року проведено онлайн опитування педагогічних працівників закладів загальної середньої освіти. Для опитування застосовувалася анкета «Виявлення соціально-психологічних проблем, породжених пандемією COVID-19 у діяльності закладів освіти» розроблена В. Г. Панком.

В дослідженні взяли участь 3209 педагогів з усіх областей України (місцеві жителі - 45\%; сільські - 55\%). За віком досліджувані були розподілені на 5 категорій: до 25 років включно -12\% від усіх опитаних; від 25 до 35 років включно - 29\%; від 35 до 45 років включно - 28\%; від 45 до 55 років 29 включно - 21\%; від 55 і більше - 10\%. 
За гендерною приналежністю переважну більшість становили особи жіночої статі (92\% усіх опитаних). Респондентам було запропоновано оцінити наявність проблеми за допомогою шкалювання, де «0» - відсутність ознаки; 1 - мінімальне значення ознаки; 10 - максимальне значення ознаки. Для загального представлення результатів відповіді можна згрупувати у 4 групи: 0 балів - «відсутність ознак» - проблем немає; 1-4 бали переважає відсутність зазначених проблем (від 1 бал - дуже рідко виникають проблеми до 4 бали - проблеми виникають часто). 5-6 балів - відчуваються зазначені проблеми, але здатний здійснювати професійну діяльність. 7-10 балів - переважає наявність проблем (від 7 балів - відчуваю проблеми що істотно впливають на здійснення проведення освітнього процесу до 10 балів - постійно відчуваю зазначені проблеми, що унеможливлює або майже унеможливлює здійснення освітнього процесу в карантинних умовах подолання пандемії).

Серед питань, які ставилася респондентам, та ілюструють прояви ускладнень у професійному житті педагогів через дистанційну роботу виокремимо такі: - проблеми, пов'язані з використанням ІКТ (відсутність компетенцій); - порушення комунікації між педагогами та батьками щодо контролю за якістю знань учнів; - неможливість виконання повного обсягу запланованих завдань та професійних обов'язків. труднощі із залученням дітей до дистанційних занять; - труднощі з дисципліною учнів на уроках; - зниження навчальної мотивації учнів; - труднощі з організацією часу (робота, відпочинок, сімейні справи, власні діти). А також пропонувалося оцінити власний емоційний стан (відчуття надмірної втоми, емоційного виснаження, зниження рівня емоційної рівноваги)

Так, за результатами опитування, педагоги визначили вираженість особистих $\mathrm{i}$ професійних проблем таким чином: - труднощі із залученням дітей до дистанційних занять - відмітили 73\% педагогів; - для 60,7\% респондентів суттєвою проблемою стали - труднощі з організацією часу (робота, відпочинок, сімейні справи, власні діти); - на неможливість виконання повного обсягу запланованих завдань та професійних обов'язків вказало - 59,6\% опитаних; - на проблеми, пов'язані з недостатньою інформаційно-комунікаційної компетентністю звернули увагу - 53,2\% респондентів; порушення комунікації між педагогами та батьками щодо контролю за якістю знань учнів відмітили - 51,1\% опитаних; $-47,9 \%$ опитаних заявили - що мають ускладнення 3 дисципліною учнів.

Самооцінювання емоційного стану респондентів представлено на рис. 1. Емоційне виснаження, зниження рівня емоційної рівноваги, надмірну втому як суттєву 
проблему, що позначається на виконанні професійних обов'язків, відзначили - 58,7\% опитаних.

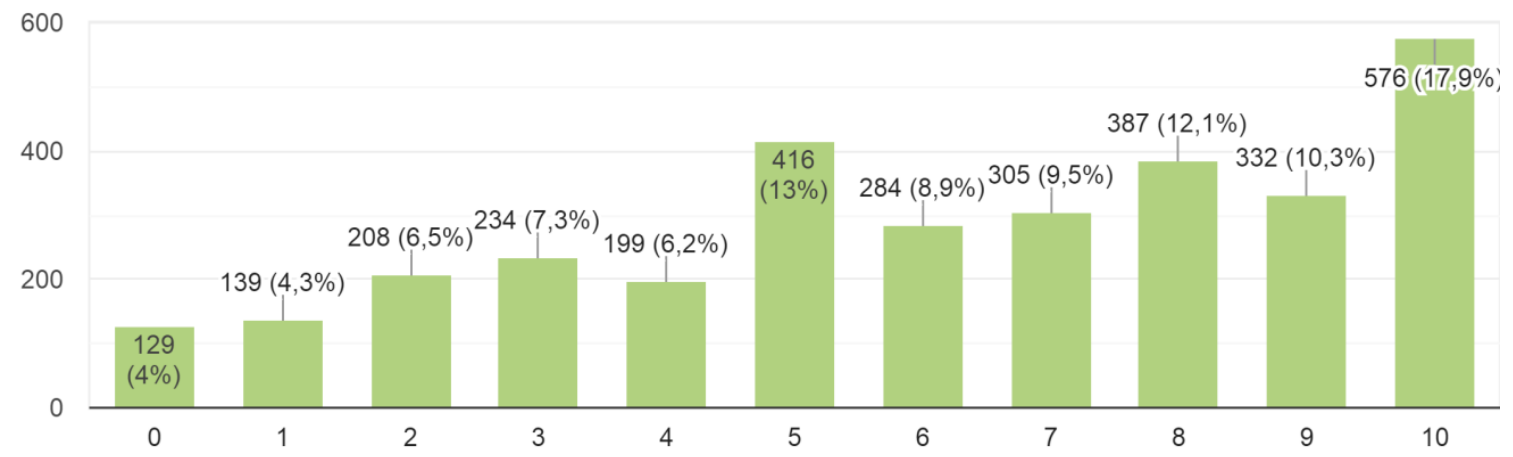

Рис. 1. Емоційне виснаження, зниження рівня емоційної рівноваги, надмірна втома

Отже зазначимо, що на даному етапі ускладнення у здійсненні професійної діяльності в умовах дистанційної роботи виникають незалежно від етапу професійного розвитку педагога, його віку, місця роботи, територіальної приналежності. Наростання негативних явищ у професійній діяльності позначається на психічному здоров’і педагогів, а саме: емоційному стані.

На основі викладеного можна визначити такі напрями для вирішення досліджуваної проблеми: педагогічний: розроблення навчальних заходів 3 організації і проведення дистанційного навчання в освітніх закладах усіх рівнів освіти 3 врахуванням різного рівня технічного забезпечення, доступу до Інтернет-мережі тощо; психологічний: здійснення психологічного супроводу професійної діяльності педагогів, який направлений на: а) розвиток стресостійкості педагогів; б) розвиток критичного мислення; в) розвиток мотивації та прагнення до професійного саморозвитку та самовдосконалення.

Дослідження виконано за грантової підтримки Національного фонду досліджень України в рамках проєкту «Подолання наслідків пандемії COVID19 у діяльності психологічної служби системи освіти», реєстраційний номер проєкту 2020.01/0114, державний реєстраційний номер $0120 \mathrm{U} 104875$. 
Aperribai L, Cortabarria L, Aguirre T, Verche E and Borges Á (2020) Teacher's Physical Activity and Mental Health During Lockdown Due to the COVID-2019 Pandemic. Front. Psychol. 11:577886. doi: 10.3389/fpsyg.2020.577886

Brackett, M., Cipriano, C. (2020) Teachers Are Anxious and Overwhelmed. They Need SEL Now More Than Ever. Available: https://www.edsurge.com/news/2020-04-07teachers-are-anxious-and-overwhelmed-they-need-sel-now-more-than-ever.

Hidalgo-Andrade P, Hermosa-Bosano C, Paz C. (2021)Teachers' Mental Health and Self-Reported Coping Strategies During the COVID-19 Pandemic in Ecuador: A MixedMethods Study. Psychol Res Behav Manag. 2021;14:933-944

https://doi.org/10.2147/PRBM.S314844

Santamaría, M., Mondragon, N., Santxo, N., \& Ozamiz-Etxebarria, N. (2021). Teacher stress, anxiety and depression at the beginning of the academic year during the COVID-19 pandemic. Global Mental Health, 8, E14. doi:10.1017/gmh.2021.14

United Nations Educational, Scientific and Cultural Organization (UNESCO) (2020) Adverse $\begin{array}{llll}\text { effects of } & \text { school } 2020 . & \text { Available: }\end{array}$ https://en.unesco.org/covid19/educationresponse/consequences.

\section{Contact information of corresponding author:}

Name, surname, title: Valentyna Horlenko

Postal Address: 13312, Zhytomyrska St. 46/1, ap. 69, Berdychiv, Zhytomyr Region

Phone: +380978345503

E-mail:vaka_orchid@ukr.net

ORCID orcid.org/0000-0003-3963-4804 